\title{
Corporate Governance in Family Businesses: The Role of the Non-Executive and Independent Directors
}

\author{
Alfred Sarbah'1, Isaac Quaye ${ }^{2}$, Emmanuel Affum-Osei ${ }^{2}$ \\ ${ }^{1}$ Institute of Distance Learning \& Continuing Education, Kumasi Polytechnic, Kumasi, Ghana \\ ${ }^{2}$ School of Management \& Economics, University of Electronic Science \& Technology of China (UESTC), \\ Chengdu, China \\ Email:sarbah@yahoo.com
}

Received 5 November 2015; accepted 26 December 2015; published 29 December 2015

Copyright (C) 2016 by authors and Scientific Research Publishing Inc.

This work is licensed under the Creative Commons Attribution International License (CC BY). http://creativecommons.org/licenses/by/4.0/

(c) (i) Open Access

\section{Abstract}

The paper investigates the challenges faced by Non-Executive and Independent Directors in ensuring that good corporate governance practices are adhered to in non-listed Ghanaian family business at all times using non-listed family business in the Ashanti Region of Ghana. The findings revealed that the presence of non-executive and independent directors had no significant effect on the performance of non-listed family businesses in Ghana since they were dormant in most of the roles expected to be discharged by them and active in only few responsibilities or roles. It is also discovered that the boards of non-listed family businesses meet only when there is a problem to solve and not regularly. The owner-manager-chief executive office-board chairman, makes all decisions and ensures its implementation. The results draw the attention of policy makers to the position of non-executive and independent directors in family businesses given the enormous positive contribution they play to the economic development of the nations and their contributions to the society in general.

\section{Keywords}

Corporate Governance, Non-Listed Family Business, Non-Executive and Independent Directors, Ghana

\section{Introduction}

The need for a good corporate governance practice in family businesses in developing countries cannot be over emphasized since these businesses contribute to Gross Domestic Product (GDP) and invariably economic devel- 
opment. An economy's corporate governance system has a significant impact on the profitability and growth of corporations, their access to capital, and their cost of capital [1]. According to Halpern, the governance system can influence the decisions undertaken by firms and ultimately has an impact on the wealth created in a country [1].

The issue of corporate governance has dominated policy agenda in developed market economies for more than two decades, and it is gradually worming its way to the top of the policy agenda on the African continent. The Asian crisis and the relative poor performance of the corporate sector in sub-Saharan Africa have made corporate governance a catchphrase in the development debate [2].

Traditionally, corporate governance has been associated with larger companies and its associated agency problems as a result of the relationships between shareholders and managers. The agency problem comes about when members of an organisation have conflicts of interest within the firm mainly due to the separation of ownership and control in the firm. It is therefore tempting to believe that corporate governance would not apply to unlisted family businesses (UFB's) since the agency problems are less likely to exist. In many instances, family businesses are made up of only the owner who is the sole proprietor and manager [3]. Basically, UFB's tend to have a less pronounced separation of ownership and management.

It is also the perception of many that because UFB's have few employees who are mostly relatives of the owner and thus have no separation of ownership and control there and therefore there is no need for corporate governance in their operations. Also, the question of accountability by UFB's to the public is non-existent since they do not depend on public funds. Most especially the UFB's do not necessarily need to comply with any disclosure. Because there is no agency problem, profit maximisation, increasing net market value and minimising costs are the common aims of the members. Members also disregard outcomes of organisational activities that will cause disagreement. They are rewarded directly and as such need no incentives to motivate them. Thus disagreement does not exist, and hence there is no need for corporate governance to resolve them.

It must be however borne in mind that, "a man who collects honey is always tempted to lick his fingers" [4]. In other words, whenever there is temptation such as the wealth generated by family business, people will always be tempted. In order to deal with these human shortcomings, corporate governance measures are required for UFB's. Unfortunately, many people only hear about corporate governance through widely reported failures such as those of Enron, Parmalat and Adelphia and others [5]. Corporate governance in many developed markets received serious attention in the late 1900's after corporate and business collapses which were attributed to poor governance practices. This development was accelerated with the onset of the Asian crisis in mid-1997 and by the early 2000 global financial crisis that started out in the US housing market, causing global economic contagion [6].

Despite these arguments, there is a global concern for the application of corporate governance to UFB's. It is often argued that similar guidelines that apply to listed companies should also be applicable to UFB's because corporate governance can greatly assist the UFB's by infusing better management practices, stronger internal auditing and greater opportunities for growth [7].

Corporate governance brings new strategic outlooks through external independent directors; it enhances firms' corporate entrepreneurship and competitiveness. It is not a threat to value creation in entrepreneurial firms if the guidelines are properly applied. Board members bring into the firm expertise and knowledge on financing options available and strategies to source such finances, thus dealing with the credit constraint problem of UFB's as well. For UFB's in particular, the role of other stakeholders must be well-articulated through a bottom-up approach where, for example, unions' views are explicitly laid out in board meetings.

In view of the above it is envisage that applying governance principles reduces the problems associated with information asymmetry and makes the UFB's less risky to invest in. However, attention should also be drawn to the disadvantages of corporate governance. The introduction of corporate governance will mean additional roles in audit, remuneration and nomination committees, new and more directors have to be hired. The non-executive directors will also have to be paid higher remuneration because of active roles they will be playing. Thus, introduction of corporate governance into activities of UFB's will increase operational costs. Nonetheless, the benefits for an economy like Ghana cannot be overlooked [8].

It must be emphasised that in today's business world the scope of family businesses has expanded to include some of the world's largest companies and their economic weight remains massive. In terms of numbers of individual enterprises they account for a significant proportion of Gross Domestic Product (GDP) in their markets. Small and Medium Scale Enterprises (SMEs) in Ghana, which are mostly family businesses, have been noted to provide about $85 \%$ of manufacturing employment and are also believed to contribute about $70 \%$ to Ghana's 
GDP and account for about 92\% of businesses in Ghana [9] [10]. Abor and Quarter [11] describe them as efficient and prolific job creators, the seeds of big businesses and the fuel of national economic engines. Even in the developed industrial economies, it is this sector rather than the multinationals, which are the largest employer of workers [12]. It therefore becomes imperative for them to be governed well and the role play by non-executive directors cannot be over-emphasised.

Private businesses have therefore significantly contributed to Ghana's sustained growth over the past decades. Among them a large fraction of businesses are organized around families. Family firms are characterized by concentration of ownership, control and often key management positions among family members. However, as they grow, they face the same challenges and pressures as any major corporation. To thrive, they must remain ahead of the competition through innovation, build strong relations with suppliers, develop a profound understanding of their customers and skilfully navigate through market changes. In addition, these businesses face distinct obstacles centred on family dynamics and expectations.

It is at this stage that the issue of Corporate Governance comes in. It requires that companies should be run in an efficient, transparent, responsible, profitable and fair manner. Transactions should be captured and recorded as true and fair record of trading and as much as possible, no window dressing, creative accounting or doctoring and massaging the figures or cooking them up. It requires that there should be no secret or off balance book accounts and that accounting records should be kept according to international financial standards or best practice. Directors are supposed to make statutory and voluntary disclosures about the company's affairs for the sake of stakeholders. They should treat all stakeholders fairly and they have the fiduciary duty of ensuring that they use their sound knowledge to manage various risks that can occur and affect the business' survival as a viable going concern. They are expected not to engage in any activity that will dent the image or reputation of the company.

It is expected that they obey the law and ensure that the legal obligations of the company are met. They have a duty to institute internal controls of checks and balances to avoid internal process failures. They have oversight functions of supervising all the functional areas and monitoring activities. They prepare the annual reports to the Annual General Meeting (AGM) and they should submit themselves to periodic appraisal and upgrade their knowledge and skills through training and self-development. They are expected to act as boundary spanners by integrating the internal and external environments of the company to avoid strategic drift.

The collective problem of business today is coming to be seen as a failure of corporate governance, meaning that far too many boards are failing to execute their duties responsibly, both collectively and individually. The critics are many and sustaining and fuelling the criticism is that fact that investors have better access to more detailed information than ever before, enabling them assess readily not only the performance of a company relative to its peers but also the lucrative agreements between boards and Chief Executive Officer's, conflict of interest and a host of other issues that historically have remained within the confines of the boardroom, largely unknown to the shareholder group [13].

Despite this growing interest, there is a general lack of understanding of the principles of effective corporate governance in family businesses. Family businesses, it has been stated, form the basic building block for businesses throughout the world. The economic and social importance of family enterprises has now become more widely recognised. Internationally they are the dominant form of business organisation. One measure of their dominance is the proportion of family enterprises to registered companies; this is estimated to range from $75 \%$ in the UK to more than 95\% in India, Latin America and the Far and Middle East. The manner in which family firms are governed is therefore crucial to the contribution which they can make to their national economies as well as to their owners [14].

A weakness of family business is the ambiguity that can occur between the different roles played by family members in the business. In this vein, it is easy to imagine that family members in senior positions sometimes need to clarify from which points they are thinking or speaking-are they being "dad" or "boss" or "majority shareholder"? [15].

This problem can further be compounded if a family business grows significantly to become a huge business entity or group of business firms. A founding owner, who is used to fulfilling many roles in running the business on his/her own, will probably have little interest in the setting of clearly articulated governance principles [16]. However, significant growth will probably require the employment of additional non-family members with an ensuing increase in the requirement for governance measures. Such measures are necessary for good communication which facilitates the management of relationships between the family and non-family managers, and especially the issue of power sharing [5]. 
The essence of the significance of governance in a family business is captured in the following quote from Professor John L Ward [17], an eminent family business researcher:

"For the family-owned business, good governance makes all the difference. Family firms with effective governance practices are more likely to do strategic planning and to do succession planning. On average, they grow faster and live longer."

From the above it may be noted that the consequences of a lack of governance can be severe. Due to notorious lack of effective communication in family business, the notion that shareholders who are active in the business withhold vital information from non-active shareholders can be strengthened [18]. Although often based on misperceptions, such a situation is ripe for accusations of unfairness, mistrust and conflict. Whatever the basis of such conflict, it can ultimately result in the destruction of a business [18].

The necessity for a good governance system in business is provided by King [4] (pp. 19-20). In his opinion investors in the equity of a business expect that the return on their investment should be higher than that which could have been achieved in a bank for reasons of the added risk involved. In this vein, investors accept the possibility that the directors of the company in which they have invested may make a wrong business judgement call. However, investors will not accept a wrong business call that was made by directors who adopted an inappropriate process in order to make their decision.

Nevertheless, directors can make good business judgement calls whilst practising bad governance. The converse of a bad judgement call supported by good governance also occurs which unfortunately, is sometimes equated to bad governance. However, in the case of a bad judgement call backed by bad governance, directors should expect a disastrous situation [4]. In echoing this sentiment, Levitt [19] as cited by Adendorff [20] (p. 213), believes that sound corporate governance makes good business sense from a purely utilitarian point of view. Her motivation is the belief that sound governance promises an increased ability to attract foreign and institutional investment, to supplement sustainable growth and to identify and manage other risks and makes a similar point in saying that governance can provide shareholders with increased confidence of an equitable return whilst providing other stakeholders with assurance towards the sustainability of the company.

It may be realised that the above seems relatively complex and applicable only to larger organisations, however good governance is critically important to all businesses [15] (p. 45), even those too small to have a properly constituted board of directors. Good governance ensures that the business has well thought-out and articulated directives that make its goals, mission and values clear to all concerned in the business. Good governance is also critical for reasons of control as it ensures that the decisions made by the owners, directors and executives serve the goals of the business and are respected throughout the organisation. In this way, good governance leads to accountability and ensures responsibility [15].

One weakness that bedevils many family business which was identified previously is the ambiguity of the different roles played by family members in a family business which can lead to confusion between the roles of management, family and shareholders [21]. Sound governance therefore promotes a clear understanding of the various role players in a family organisation and what their roles are. Additionally, good governance supports transparency and trust which are vital towards fostering shareholder commitment and bettering company performance. In this way, the long-term sustainability of a family business is assured [15].

Apart from role ambiguity, sound decision-making and governance structures supported by effective communication are often lacking in family business [18]. An example of this is the perception that non-active shareholders often have of active shareholders in the business. Active shareholder are often perceived to begrudge requests for dividends or even provision of information to non-active shareholders. In the absence of shared information promoted by sound governance, the resulting knowledge vacuum provides a fertile breeding ground for mistrust and conflict which is often based on misperception [18]. Clearly, a lack of governance can have major consequences in relatively normal circumstance due to the complexity of family business. However, when it comes to handling conflict in a family business, a lack of governance can be an even bigger problem. An oftmade mistake in family business in times of conflict, involves the employment of short-sighted and dysfunctional approaches to "handle" issues rather than the installation of sound governance [22].

One body that sees to the adherence of corporate governance in business is the board of directors. The board should be made up of both executive and non-executive or independent directors. The elected directors assumes the obligation to represent the interest of the owners of the business thus undertaking a serious fiduciary responsibility. Effective representation therefore requires more than integrity since it also requires the competence to make sound decisions. The executive directors owes office or a place of profit under the company other than the 
office of the auditor. In view of that their judgment, when it comes to issue of corporate governance, may be clouded. To avert this situation business are allowed to have non-executive or independent directors who shall have the overall responsibility for the leadership and control of the company.

The responsibility for ensuring a company complies with good corporate governance therefore lies on the board of directors. However, for the executive directors this responsibility may well conflict with their obligations to make commercial decisions to develop a company's business. Accordingly, much of this responsibility will fall on the non-executive directors. This paper therefore seeks to ascertain the role that non-executive and independent directors play in ensuring that family business adhere to good corporate governance and the challenges they face. In doing this family businesses in Ghana have been selected as case study.

\section{Literature Review}

\subsection{Meaning of Family Business}

The term "family business" has been used several times without having a clear definition of just what a family business really is. As Handler said: "to define family business is the first and most immediate challenge for the researcher" [23]. That is because family businesses cover a very wide scope, include many types, the factors involved are very complex. In their editorial note in the first issue of Family Business Review, Lansberg, Perrow, and Rogolsky asked: what is a family business? [23] The question continues to be asked because definitions of family business abound in the literature [24] and definitional ambiguities persist [25].

Researchers generally agree that family involvement in the business is what makes the family business different [26]. Most researchers interpret family involvement as ownership and management [23]. Churchill and Hatten prefer to add to this the existence of a family successor [27]. One could interpret this to imply that the family-owned and operated ethnic restaurant or farm, where the next generation is being educated to become professionals rather than to continue in the restaurant or farm business, is not a family business.

Glancing through the literature, it can be realised that from 1989 to 1999, 44 research papers each offered a different definition of family business [28]. Astrachan and Shanker put forward a classification of definitions as narrow, middle or broad [29]. The broad definitions refer to businesses in which family members exercise some control over the strategic direction of the company, but do not necessarily work in the business. The middle range includes family businesses where either the founder or a descendant of the founder runs the company and the plan is for the business to be passed on to another generation. The narrowest definition is one where multiple generations are involved in the business ownership and where more than one family member is involved in the management of the company. Litz also sought to differentiate definitions based on family involvement and intent [30].

The legal, governance, and financial frameworks of family businesses are not universal and therefore historians and management specialists have found definitions remarkably hard to pin down and this is well reflected in the literature. It is no surprise, therefore, that there is no general consensus among scholars as to what constitutes a family business in quantitative, qualitative terms or historical terms [23] [31]-[34].

In a recent review of different definitions of a "family business" Brunaker [35] [36] concludes that one or several of the following criteria are used: ownership control within a family, family management, and realized/intended leadership succession within the family. Hoy and Verser [37] also indicated that different elements of the definition do not always coincide. Professional managers or a whole family may, for example, be hired to run a company belonging to a business group. When the firm grows, owners may become directors and then there is a need for a professional management structure [38]. The emergent "new economy" may motivate a review of the definition of the family business; the Schumpetarian image of the entrepreneur as a builder of an empire for generations to come seems overly optimistic. Instead the entrepreneur over her/his lifetime may run several firms in parallel and/or sequentially. Nevertheless, here a family owner-managed company is considered to be a family business if perceived as such by the owners.

However, after comparing and analysing the different viewpoints, it can be concluded that family business is when a family or several close families own all or major part of the ownership, and control all or part of the management authority, the enterprise is family business. In summary, there appears to be total agreement that a business owned and managed by a nuclear family is a family business. Generally speaking, the family must hold ownership of the family business in an absolute or relative advantage, at the same time family and family members have a certain degree of involvement in the business management process. 
Family businesses therefore constitute the world's oldest and most dominant form of business organizations. In many countries, family businesses represent more than 70 percent of the overall businesses and play a key role in the economy growth and workforce employment. Family-owned businesses account for two-thirds of the world's businesses and generate most of the world's economic output, employment and wealth. In the UK, the Institute for Family Business estimates that family firms account for 65 percent of all private sector enterprises and more than 30 percent of GDP. Studies by McKinsey, the Harvard Business Review and others show family-owned companies outperforming their non-family counterparts in terms of sales, profits, and other growth measures.

\subsection{Meaning of Corporate Governance}

The Corporate governance literature affirms that corporate governance is one of the important factors influencing performance [39]-[47]. Defining corporate governance however is a difficult exercise because of the different culture, legal systems and history [48]. Furthermore there are a variety of definitions that has emerged from the existing literature. There are however many different features describing corporate governance system, in each country. Differences regard, mainly, stage of economic development, country's legal tradition (common or civil law), development of stock market, capital and ownership structure and business practices.

It can be defined as the ways in which suppliers of finance to a firm assure themselves of a good return [39]. However this definition does not take into account the relationship between the stakeholders in the company and those who manage its affairs. It follows that corporate governance should include the structure and functioning of Boards of Directors as well as the rights and prerogatives of shareholders in boardroom decision making. Accordingly corporate governance could be referred to as a collective group of people united as one body with the power and authority to direct, control and rule [49].

Corporate governance is associated with the way firms are managed and controlled. There are many differences in what the underlying principles and methods applied are. These differences can take several forms. Most pronounced is the difference between the Anglo Saxon corporate governance system of "outsider control" and the European one of "insider control".

In the Anglo Saxon system, managers are monitored by the external market and by the board of directors which is usually dominated by outsiders. In contrast, in most of the European and in the Japanese governance systems managers are allegedly monitored by a combination of financial institution, large shareholders and inter-corporate relationships that are maintained over long periods. Good corporate governance contributes to sustainable economic growth and development by enhancing the performance of companies and institutions and thereby increase access to outside credit.

The issue of corporate governance has received a lot of attention after the 2008 global credit crunch that culminated into bank failures and worldwide economic crises. However it must be stated that corporate governance covers a wide scope. Basically, good corporate governance includes holding regular meetings by the board of directors to discuss issues concerning the company, keeping minutes of decisions or written consents made by the board, making records of the actions available to all stakeholders, approvals, and critical decisions of the organization. It also includes keeping to the requirements of the law with regards to ensuring that filings are up to date. Corporate governance also includes keeping a close eye on the financial statements as well as the people producing those statements. It also includes encouraging an attitude of openness to differing perspectives within the board or among the executive team members. It may also include adopting various policies that guide the operation of the business: for example, conflict of interest policies; diversity policies; investment policies; and privacy policies.

Due to the nature of corporate governance and its requirements, some family business owners may believe that attention to corporate governance is unnecessary because there is general agreement on the operation of the business, and no one (other than, perhaps, the Internal Revenue Service) is looking over the shoulders of management to evaluate how things are done. Perhaps the business has operated for generations with management by consensus, expressed verbally and not committed to writing.

However, this assertion is wrong because circumstances can change: family disputes may arise; long-simmering resentments may bubble to the surface; the business may hit a rough patch; and creditors may be looking for opportunities to enforce claims against shareholders or directors of the company. It is not only when things start to go wrong that the level of attention to corporate detail should become a factor in family businesses. 


\subsection{Why Family Businesses Need Corporate Governance}

Most small independent companies are family businesses; most family businesses are also small. In most small family businesses management and ownership coincide. In view of this the need for good corporate governance practices in family businesses cannot be underestimated. Smaller family-owned businesses are often operated with a degree of informality that is both natural and efficient. The thought is that "corporate governance norms" are for someone else's business - the big guys with their in-house lawyers or big legal budgets. That attitude can be costly, particularly for a smaller, owner-operated business.

Family business governance encompasses both corporate governance, typically in the form of a board of directors, and family governance, typically in the form of a family council. Within each, there are many choices regarding degree of formality and levels of participation. There is no "one-size-fits-all", and while there are certainly "best practices" for each, even the best of these requires adaptation in order to function well in each individual family and family business circumstance. Family businesses are fundamentally different in corporate governance from widely held public companies. This differences derive primarily from the discrete nature of their ownership. Family ownership concentrates control and allows greater agency in governance.

\subsection{Non-Executive and Independent Directors in Family Business Corporate Governance}

The role of the board of directors and in particular the non-executive directors in ensuring that organisations adhere to good corporate governance practices is worth mentioning. These non-executive directors plays important roles on the compensation, audit, nominating and other important committees to ensure that appropriate procedures are followed. This study therefore aims at investigating the roles of non-executive directors in non-listed family businesses in Ghana in ensuring good corporate governance practices in these institutions are adhered to at all times.

The board of directors is regarded as one of the most critical governance mechanisms in all and medium-sized family businesses [50]. Corporate family business boards of directors in the founder's generation may be simple statutory boards created merely to satisfy legal requirements. These early boards may include a family member (e.g. Spouse) and/or a trusted advisor (e.g. Corporate Attorney). When a business gets more complex, the skills needed may exceed the capabilities of the founding family. It is inevitable then that more non-family members will occupy senior management roles. This will have implications for board structure and size.

The core roles of a well performing board of directors are to set the overall strategy of the firm; oversee the management performance; and ensure that an appropriate corporate governance structure is in place, including a robust control environment, sufficient disclosure levels, and an adequate minority shareholders' protection mechanism. The amount of time and effort allocated by the board to each of these areas will depend on the size and complexity of the family business.

The board should make two contributions to the firm:

1) Overseeing the managerial activity (monitoring);

2) Offering expertise, knowledge and support to the management (resource provision).

While there is no single best structure of a family business's board of directors, there is broad support for the importance of board independence, as the presence of independent directors on the board reduces the risk of appropriation of private benefits. The importance of board independence has stimulated a range of studies centred on the relation of board independence to firm-level and country-level characteristics. Once a family business has outgrown the point where the founder, or family partnership, can effectively manage the firm, the establishment of a board of directors becomes necessary [18]. By following this route, a family business progresses from an organisation in which family relationships are dominant to an organisation based primarily on business relationships. In parallel, the informal structure of a family business inherited from its formative years is replaced by a more formal structure in which responsibilities are clarified and the process for taking decisions becomes more regulated [5].

The role that boards play, even in small family businesses, is attracting increasing attention within rationalchoice frameworks. Agency theory and resource arguments from the strategy literature [51]-[55] even indicate that boards may have a more important role in small businesses than in corporations. The information gap between the small-business owner-manager and important stakeholders is especially wide in the small business. Another reason for opening up to external participation on the board is that family businesses run the risk of in-breeding [26]. Active boards in small businesses may also have a disciplining role, often producing formal 
planning processes that make the small-business owner-manager more aware of managerial aspects of his own business. Accordingly Dyer [56] the board is an important component of the culture of in the family business.

In the corporate governance literature, there are basically two theories commonly applied to corporate entities in general. The first is the agency theory which espouses the view that, in the context of a board, directors are seen as agents and managers of the institution whose vital task is to protect the interests of only the shareholders as residual owners of the company. They monitor the chief executive officer and the implementation of corporate strategies, determine the level of executive pay, plan for company succession, and provide overarching supervision. These activities and functions allow the directors to ensure that officers are performing their roles in alignment with the interests of the shareholders.

The second theory, the Stewardship theory, is keenly interested in ascertaining that the directors' interests and motivations are aligned with the goals and objectives of the organization as a whole. This means that the steward's interest is aligned with the stakeholders'. Under this theory, the board's primary role is to service and advice, rather than to discipline and monitor, as agency theory prescribes. Where stewards are engaged to manage the affairs of the business. they emphasizes:1) values of service over self-interest; 2) responsibility by prioritizing long-term gains and values over short-term, myopic greed; 3) and develops good governance, clear working processes, open communications, and encompassing empowerment. Collectivist and stakeholder-oriented, stewardship fittingly applies to the family business model setting.

A board dominated by insiders or company-affiliated directors (also known as "grey directors") has been suggested to be a correct match for a company practicing stewardship. However, this may not always be the case. More and more, family-run businesses, big and small, are revamping their board of directors by putting more independents than insiders or grey directors on their boards. A majority of family businesses should in fact welcome independent directors into the boardroom. Transparent processes, good governance, and an empowering atmosphere are the general results of placing independents in a board.

Independent directors can help family companies find a way to balance the dynastic expectations of a family with the needs of the business. Their primary purpose of a Non-Executive Director (NED) is to bring objective scrutiny on behalf of the shareholders. To that end, the importance of true independence of thought cannot be overstated. The best NEDs are reflective and thoughtful in their approach, ask the tough questions and offer considered advice based on sound judgement. They must maintain integrity and have strong principles.

Because independent directors have no existing loyalties to family members or preconceptions about the business, they are particularly well placed to provide advice on contentious issues such as board appointments, succession planning, remuneration and retirement. They should insist that the right thing is done for the company and must not be "followers of fashion". They must have sufficient wisdom to perceive whether a course of action is morally dubious or financially risky. If so, they should exhibit the courage to disagree, and if the problems are systemic, to depart.

The independent directors balance their strong viewpoints with a supportive style in the boardroom. They are able to probe and challenge the executive team on thorny subjects without creating conflict. While asking the difficult questions is the primary task, they should also offer support and guidance on problematic issues. Maintaining a constructive and diplomatic style is important at all times.

Independent directors can play a vital role in business development, providing fresh perspectives, a strategic overview and opening up valuable networks for the business. They can also act as a sounding board for the non-family CEO and mentor young or aspiring family executives, passing on experience drawn from a wide range of companies and business challenges [57].

In companies where the founder is also the CEOs he/she may be too attached or too close to the enterprise, [58] feeling that it is a legacy handed down by esteemed forefathers or a legacy they are handing down. They may be too sympathetic with workers' plight, or too caught up with the notion of family and close family ties.

In other circumstances, a CEO may also overreach [59] and be too self-absorbed or may not want to relinquish the power and authority he earned throughout the years. Instead of identifying redundancies that may impede efficiency in the business, he may retain employees who serve the same function out of loyalty. This act of the founder CEO may be to the company's detriment in the long-run. As Dyer put it: "because founders are often reluctant to have a governing board review their decisions, there are no checks and balances. Without an outside perspective to give the decisions a 'reality check' ...there is a strong possibility that the business will join 70 percent of those that fail in the first generation. In a number of cases, we have seen founders who, because of poor information or because of age and senility, make decisions that destroy the business" [60]. 
In situations like these the services of independent directors comes in needy, this is due to their detached relationships with the company and lack of any special or financial relationship with its members, and so they fill in the gap as objective and emotionally-detached arbiters. They help keep the balance of the ship and provide the captain with relevant information and corporate wisdom that will steer the firm away from disaster. Playing both the hull and the keel, they are able to perform an effective role as to where the company is sailing.

Known by some as strangers and outsiders, independent directors possess the qualities that a successful family CEO or entrepreneur may lack. They similarly have the prerogative to recommend an alternative course of action, redirect business goals, constructively criticize management programs, and advise on matters pertinent to corporate growth. They may also fill in any skills or networking gaps that hound the owners. Similarly, independent directors "deal with the pragmatic realities and idiosyncrasies of the family owners." [60] At bottom, independent directors are not powerless or impotent in any way. In fact, they may sometimes be viewed with a suspicious and envious eye by family members, both within and outside of the board, as they may be a repository of authority.

According to Howard Fischer and Jane Stevenson, "To create the ideal board for your company, you need outside directors who will hold you accountable. You should have the right mix of talents, personalities, and experience. Above all in a family company, you need people with high emotional intelligence.” [61].

In spite of the fact that independent and non-executive directors wielding tremendous authority or the potential to be very influential, they often face opposition from within the board and beyond it. Instead of being supported as steward-arbiters, they may be showered with scepticism and distrust, if not malice. Because of the familial and relational setting of a family business is not traditionally open or receptive to strangers. According Donald Jonovic, "They are used to playing close to the chest, so bringing in an outsider is like disrobing in front of a stranger for the first time. Taking that initial step is hard to do.” [62]. The reason for this is simple: as a close corporation, they are accustomed to working with dad or mom, with an uncle or an older sibling. In-house supervision and advising is enough; bringing in a boardroom "policeman" from the outside is suspicious. The introduction of an independent director to the board-which could be interpreted as the arrival of a professional critic with policing functions but who has contributed nothing to the corporation's working - may be the sign of a shake-up that some family members, including the company president and chairman, fear [63]. As a corollary, independent directors are accused of not knowing the business and/or the industry to be worthy of any policing functions [64].

\section{Hypotheses Formulation}

The empirical evidence of independent and non-executive directors and firm performance is mixed [65]. Studies for example by [66]-[69] found a positive impact from appointing independent and non-executive directors onto the board. Rosenstein and Wyatt [70] show that the firm share price goes up when an additional outside director is appointed. Several other empirical studies, however find either no significant effect or negative effect of outside directors on firm performance [71] [72]. This is supported by studies conducted by Rashid et al., [65] which concluded that independent and non-executive directors are good monitors but cannot add economic value to firms in Bangladesh. This paper sought to investigate whether various roles played by independent and non-executive directors have significant or positive impact on the performance of non-listed family businesses in Ghana.

\subsection{Strategy Formulation}

In contrast to the Financial Reporting Council (FRC) guideline, it appears that non-executive directors have a limited role in strategy development on listed boards; strategy sessions are infrequent and executive-led, often planned as annual or biannual events [73], a format which has not changed since the early 1990s [74]. However, non-executive directors on unlisted boards have a greater involvement in strategic development [75]. Executive directors are often less experienced, and shareholder agendas are transparent; non-executive directors readily align themselves with shareholders, managing disparate interests across shareholder groups in order to achieve common strategic goals. Decisions evolve through complex, non-linear and fragmented processes over time, and are conducted as a continuous debate. Research suggests that in order for a company to survive and prosper, it must remain flexible and responsive to changes in its own performance levels and to changes in its environment [76]; Long et al., [75] indicates that unlisted companies are very sensitive to environmental changes, and suffer 
from fewer and less robust internal resources, encouraging non-executive directors to be more flexible, opportunistic and involved in their approach to strategic development than on a listed board [75]. This leads to our first hypothesis:

H1: Strategic formulation as a role of Non-executive directors has a significant positive impact on the performance of family businesses.

\subsection{Selection and Removal of Executive Directors}

Agency theory suggests that the market for corporate control can curb the self-interested behavior of senior executives; if executives are underperforming, and existing shareholders do not replace them in a timely fashion, external investors can purchase the firm and replace both the board and the management [77]. Emphasis on the monitoring role encourages non-executive directors to overturn poor decisions, or replace underperforming executives as a result of such monitoring in a timely fashion [78]. Due to the formal channels of communication within listed companies, and the increasing external attention on corporate governance and proper process, the process of appointing and removing directors is highly structured and transparent, making employee expectations easier to manage.

However, a study by Long et al., [75] posits that there is a more complex alignment between shareholders and executives, often inextricably linked by ownership of equity amongst executives and a blurring of board roles. They [75] further stated that selecting, appointing as well as removing directors can illuminate strong personal and emotional opinions based on individual history and culture amongst incumbent shareholders and executives; unlisted companies can hire and fire without attracting the attention of external constituencies or the requirement for board sanction, and there is further evidence that dominant shareholders impose undue pressure and lessen non-executive activity. This leads to our second hypothesis:

H2: Selection and removal of executive directors as roles of Non-executive directors have a significant positive impact on the performance of family businesses.

\subsection{Succession Planning}

For non-executive directors, the identification of a competent heir apparent not only smoothes routine CEO succession, but also provides insurance should anything unexpected happen to the incumbent CEO [79] [80]. External visibility, shareholder activism and regulation have influenced the way that listed companies approach succession planning, and there is now an obligation to discuss the process in a transparent and timely fashion [75]. Independent and non-executive directors on unlisted boards have a lesser involvement in the process of succession planning. Companies are less influenced by isomorphic pressure and external visibility, and succession planning is often characterized by severe internal political manipulations and power struggles [81], largely determined by the distribution of power among the parties involved [82]-[84]. External candidates may be more difficult to attract, and there are fewer internal candidates. Furthermore, shareholder dominance increases the sensitivities; in both family-owned and venture capital-backed companies, shareholders have a direct influence on the composition and succession of the senior management team, discouraging independent views. The third hypothesis is therefore formulated as:

H3: Succession planning as a role of Non-executive directors has a significant positive impact on the performance of family businesses.

\subsection{Financial and Management Performance Monitoring}

Independent and non-executive directors on unlisted boards have a greater involvement in the monitoring of financial information. UFB's suffer from inconsistent information due to vague divisions of responsibilities, the absence of formal reporting systems [85] and the lack of human resources [86], rather than political manipulation. Informal communication channels allow independent and non-executive directors the freedom to ask for detailed financial information in a direct way and to offer additional expertise. Non-executive directors on unlisted boards have a reduced need to monitor executives due to the lack of agency issues [87] [88]; personality traits and the natural chemistry between directors are suggested to be magnified [89], and information asymmetry and opportunism is lessened through close working and personal relationships between executives and nonexecutive directors [90]. Non-executive directors have a limited role to play; dominant shareholders determine 
executive objectives and are incentivized to monitor their process. The fourth hypothesis is therefore formulated as:

H4a: Financial monitoring as a role of Non-executive directors has a significant positive impact on the performance of family businesses.

H4b: Management Performance monitoring as a role of Non-executive directors has a significant positive impact on the performance of family businesses.

\section{Methodology}

This study aimed at investigating the role of the non-executive and independent directors in family businesses, paying particular attention to the experience they bring to such boards and their "policing" role. The researchers adopted the descriptive correlation method in the conduct of this study. However, both qualitative and quantitative research approaches were adopted for this study. The population of the survey constituted owners, managers and directors of family businesses. The respondents were given two weeks to complete their questions after which a follow up interviews were also conducted.

The questions were made of both open ended and closed ended questions to enable participants expressed themselves well. Six family businesses were observed for the current study and the quantitative survey results for this study collected a total number of 180 samples out of which 12 observations were discarded due to being improperly completed. Consequently, the total number of observations studied in this analysis were 6 family businesses and 168 people made up of family members and non-executive and independent directors were interviews and questionnaires applied to. Purposive sampling method which is also known as judgmental sampling method was used in selecting the businesses. This is the deliberate selection of the particular units of the universe constituting a sample on the basis that the small number so selected out of the large one will typically be representative of the whole. Purposive sampling enables the researcher to use his or her judgment to select cases that will best answer his or her research question(s) and to achieve his or her objective. Questionnaire was the main instruments used for the study. A total of one hundred and eighty (180) questionnaire were administered over a period of six weeks in the Ashanti Region of Ghana and one hundred and sixty-eight (168) were returned representing a response rate of $93 \%$. After the data collection it was analysed using appropriate statistical tools. The questionnaire survey achieved a about 93\% response rate. The data from all 168 responses were coded and transcribed which is the process of coding to convert responses into a form that a computer can analyse. The data corresponding to the values in the Likert Scale were entered for each statement in the questionnaire. It was then checked for accuracy, through three rounds of visual and hardcopy inspections. Graphs were used to represent the demographic characteristics, Pearson Moment Correlation Coefficients was used to find out the relationships between the variables under study. Finally, multiple regression using the enter method was run to find out the impact of the roles Non-executive directors on the performance of family businesses.

\section{Results and Discussion}

\subsection{Demographic Characteristics of Respondents}

Five family firms were contacted for the current research. A total of 168 employees participated in the study. Out of the total of 168, 113 (67.3\%) were males and 55 (32.7\%) were females as illustrated in Figure 1. With regard to age, 25 (14.9\%) were within the age group of 25 - 30, 24 (14.3\%) fall within the age group of 36 - 40, 36 (21.4\%) were within the age range of $\geq 51$ which shows that majority of the sample were 51 years or above.

The age group of the respondents is depicted in Figure 2. Out of the total of 168 sample, 52 (30.9\%) had completed high school, 81 (48.2\%) hold bachelor's degree, 30 (17.9\%) were master's graduates and 5 representing 3\% had their research degrees. 63 (37.5\%) of the sample were single, 102 (60.7\%) were married and 3 (1.8\%) were divorced. The educational levels and marital status of the respondents are graphically illustrated in Figure 3 and Figure 4 respectively.

\subsection{Correlation Matrix}

Table 1 presents the correlation among the dependent variable (Performance) and the independent variables (Selection and Removal of Executives, Management Performance Monitoring, Succession Planning, Financial Monitoring and Strategic Formulation). 


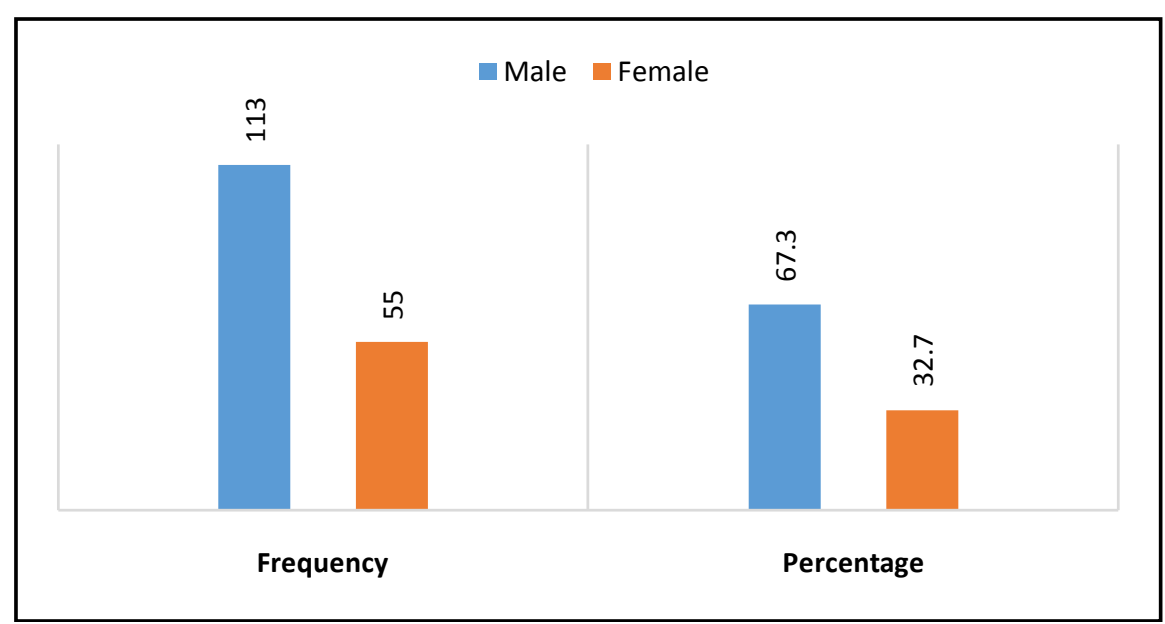

Figure 1. Gender distribution of respondents. Source: Field survey (February, 2015).

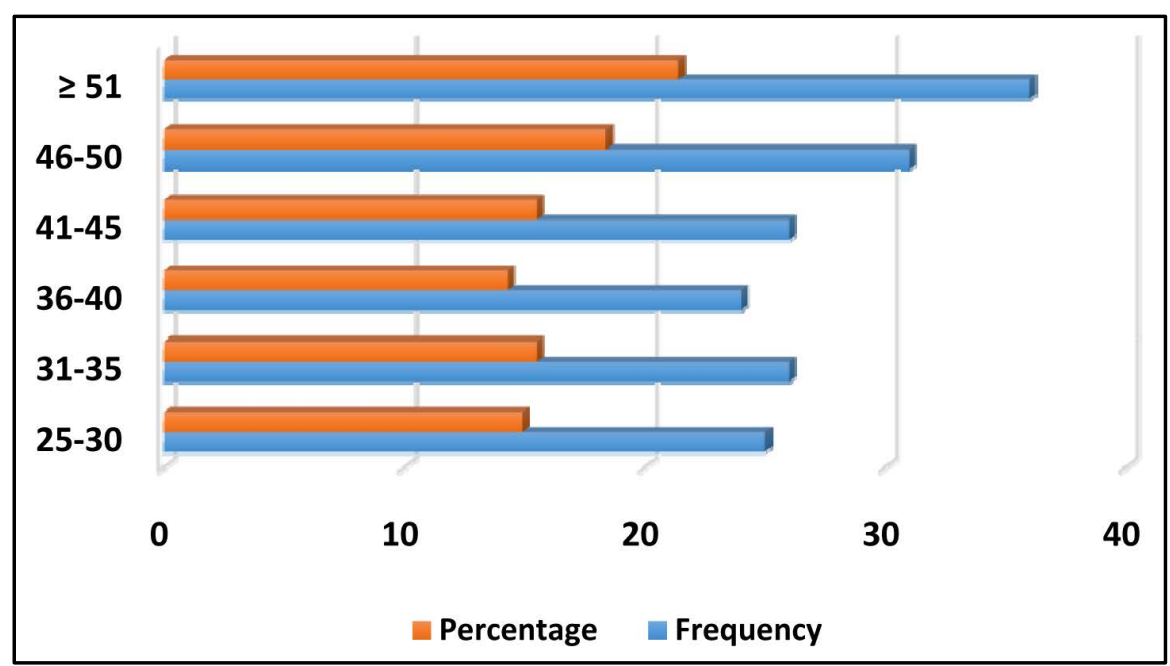

Figure 2. Age group of respondents. Source: Field survey (February, 2015).

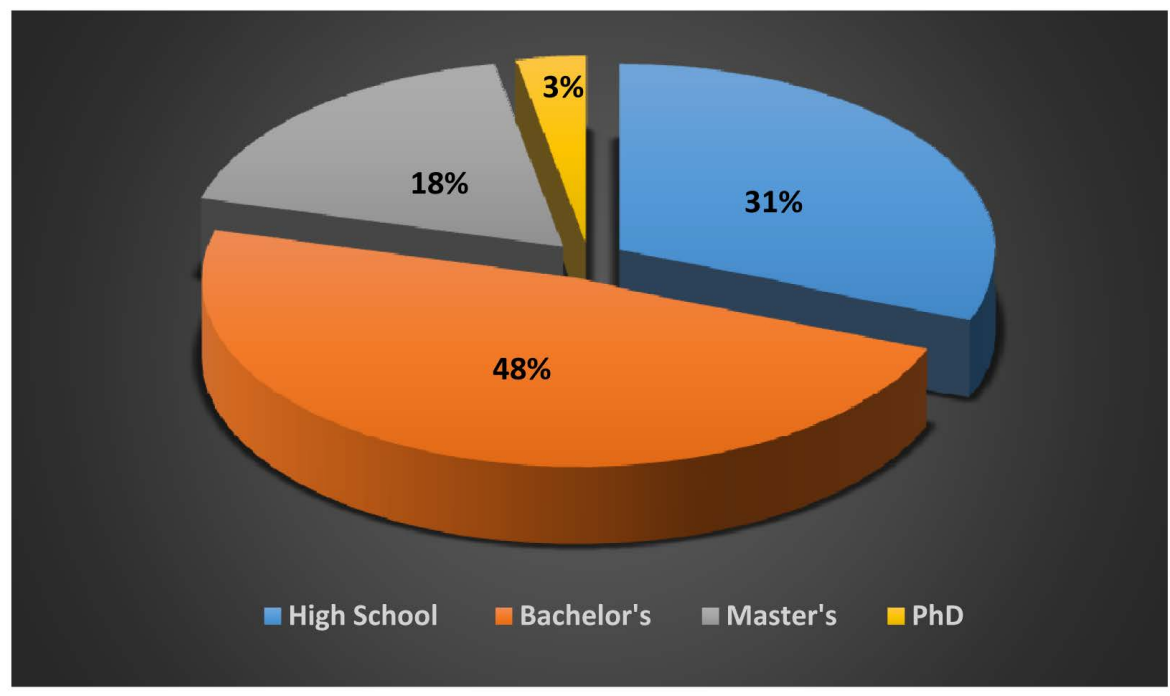

Figure 3. Educational levels of respondents. Source: Field survey (February, 2015). 


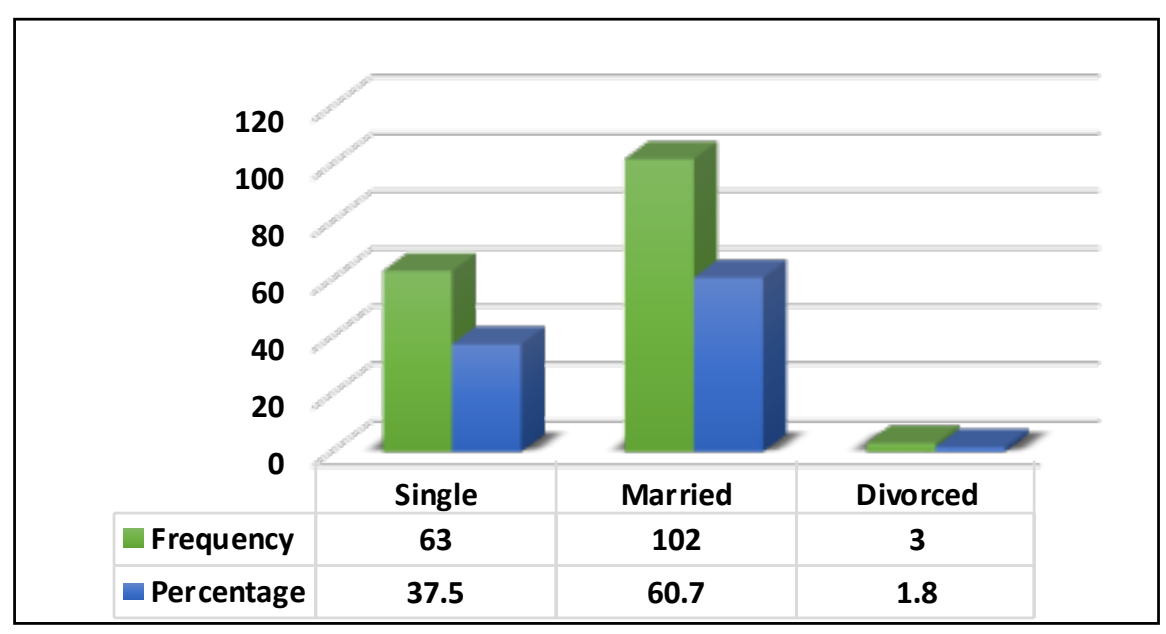

Figure 4. Marital status of respondents. Source: Field survey (February, 2015).

Table 1. Descriptive statistics and correlation of the main variables in the study.

\begin{tabular}{|c|c|c|c|c|c|c|c|c|c|}
\hline Variables & $\mathrm{N}$ & M & SD & 1 & 2 & 3 & 4 & 5 & 6 \\
\hline 1. Performance & 168 & 34.81 & 9.81 & & & & & & \\
\hline 2. SRE & 168 & 20.33 & 4.28 & 0.1 & & & & & \\
\hline 3. MPM & 168 & 28.11 & 6.83 & $0.43^{* *}$ & $0.26^{* *}$ & & & & \\
\hline 4. SF & 168 & 23.33 & 5.26 & $0.20^{* *}$ & -0.1 & $-0.4^{* *}$ & & & \\
\hline 5. SP & 168 & 25.63 & 3.36 & 0.05 & 0.1 & 0.04 & -0.03 & & \\
\hline 6. FM & 168 & 38.65 & 8.43 & $0.37^{* *}$ & -0.01 & $0.38^{* *}$ & 0.21 & 0.05 & 1 \\
\hline
\end{tabular}

${ }^{* *}$ Correlation is significant at the 0.01 level (2-tailed). Note: SRE = Selection and Removal of Executives, MPM = Management Performance Monitoring, SP = Succession Planning, FM = Financial Monitoring, $\mathrm{SF}=$ Strategic Formulation.

Table 1 shows the descriptive statistics and correlation coefficients of the dependent variable and the independent variables in the study. Performance of family business shows mean of 34.81 with a standard deviation of 9.81. Selection and removal of executives recorded mean of 20.33 with standard deviation of 4.28. Again, the mean of management performance monitoring of 28.11 has a standard deviation of 6.83. Furthermore, strategic formulation recorded mean of 23.33 with 5.26 standard deviation. Succession planning has a mean of 25.63 with a standard deviation of 3.36. Lastly, the mean of financial monitoring was 38.45 with a standard deviation of 8.43. The results show no significant relationship between family business performance and selection and removal of executives $(r=0.10, p=0.01)$. Management and performance monitoring was significantly related with performance $(r=0.43, p=0.01)$. Again, there was significant correlation between strategic formulation and performance of family businesses $(r=0.20, p=0.01)$. However, performance was not significantly related to succession plan $(r=0.05, p=0.01)$. Performance was significantly related to financial monitoring $(r=0.37, p=$ $0.01)$.

\subsection{Regression Analysis}

Table 2 shows the regression analysis. The multiple regression was run to find out the impact of the predictor variables on the criterion variable.

Table 2 shows the standard multiple regression to determine the impact of the predictor variables on the criterion variable. To measure multicollinearity problems, Variance inflation factor and Tolerance were computed. The table shows that the tolerance values range from 0.667 - 0.98 and the VIF values range $1.020-1.500$ which is less than 10. This shows that, there was no significant instances of multicollinearity and therefore, multiple regression analysis was appropriate to be conducted. The model derived correlation coefficient of $(\mathrm{R}=0.493)$ which show a weak positive linear relationship among the variables under study in the model. The $\mathrm{R}^{2}$ in the 
Table 2. Multiple regression results.

\begin{tabular}{|c|c|c|c|c|c|c|c|}
\hline \multirow[b]{3}{*}{ Variables } & \multirow{2}{*}{\multicolumn{2}{|c|}{$\begin{array}{c}\text { Unstandardized } \\
\text { Coefficients }\end{array}$}} & \multirow{3}{*}{$\begin{array}{c}\text { Standardized } \\
\text { Coefficients } \\
\text { Beta }\end{array}$} & \multirow{3}{*}{$\mathrm{t}$} & \multirow{3}{*}{ Sig. } & \multicolumn{2}{|c|}{ Collinearity Statistics } \\
\hline & & & & & & Tolerance & VIF \\
\hline & B & Std. Error & & & & & \\
\hline (Constant) & 9.629 & 6.523 & & 1.476 & 0.142 & & \\
\hline SRE & 0.23 & 0.105 & 0.009 & 0.126 & 0.451 & 0.908 & 1.102 \\
\hline MPM & 0.403 & 0.098 & 0.343 & 4.098 & 0.000 & 0.667 & 1.500 \\
\hline SF & 0.006 & 0.124 & 0.004 & 0.047 & 0.563 & 0.800 & 1.250 \\
\hline SP & 0.137 & 0.119 & 0.08 & 1.152 & 0.251 & 0.981 & 1.020 \\
\hline FM & 0.257 & 0.078 & 0.244 & 3.284 & 0.113 & 0.843 & 1.186 \\
\hline Note: & $\mathrm{R}=0.493$ & $\mathrm{R}^{2}=0.243$ & Adj. $\mathrm{R}^{2}=0.219$ & $\mathrm{~F}=10.388$ & $\mathrm{p}=0.000$ & & \\
\hline
\end{tabular}

Note: VIF = Variance Inflation Factor, Predictors (Constant) SRE = Selection and Removal of Executives, MPM = Management Performance Monitoring, $\mathrm{SF}=$ Strategic formulation, $\mathrm{SP}=$ Succession Planning, $\mathrm{FM}=$ Financial Monitoring. Dependent Variable $=$ Performance of Family businesses. Note: SRE = Selection and Removal of Executives, MPM = Management Performance Monitoring, SP = Succession Planning, FM = Financial Monitoring, SF = Strategic Formulation.

model derived 0.242 which indicated that, $24.2 \%$ of the total variability in the dependent variable in predicted by the independent variables. The Adjusted $\mathrm{R}^{2}$ also shows 0.219 which indicate $21.9 \%$ of the changes in the performance of family business can be explained by the model. However, about $78.1 \%$ of the variability cannot be explained by this model alone. The F statistic derived 10.388 indication that, the model has some explanatory power in predicting the dependent variable $(\mathrm{F}(5,162)=10.388$. The model gives the coefficients of the predictors in the model. It can be seen that, selection and removal of executive was not a significant predictor of growth of family businesses $(\beta=0.009$, $\mathrm{t}(162)=0.126, \mathrm{p}>0.05)$. However, Management performance monitoring significantly predicted performance of family businesses $(\beta=0.343$, t $(162)=4.098, \mathrm{p}<0.05)$. Again, strategic formulation was not significant predictor of the performance of family businesses $(\beta=0.004, \mathrm{t}(162)=$ $0.047, \mathrm{p}>0.05)$. Furthermore, succession planning could not predict performance of family business $(\beta=0.08, \mathrm{t}$ $(162)=1.152, \mathrm{p}>0.05)$. Lastly, the financial monitoring of non-executive directors in family businesses could not significantly impacted on the performance of the family businesses $(\beta=0.244, \mathrm{t}(162)=3.284, \mathrm{p}>0.05)$.

\section{Discussion}

We did not find a significant relationship between strategic formulation as a role of Non-executive directors and performance of non-listed family businesses in Ghana. Thus, Hypothesis 1 was not supported. Strategy Formulation is often considered to be the function of the board of directors especially when it comes to non-listed family businesses. Among the 168 respondents, $41 \%$ or $24.40 \%$ agree that non-executive and independent directors are actively engaged in strategy formulation. In the process of strategy formulation, there is always consultation between them and management team. As a result, they often work with various sub-committees when it comes to this task. In the process of strategy formulation, there is always consultation between them and management team. As a result, they often work with various sub-committees when it comes to this task. 60.12\% denoting 101 respondents explained in an interview that they have nothing to do with strategy formulation at all since the management team formulates all the strategies. However, the non-executives and independent revealed that management team considers them as problem-solving machinery since they are only called in whenever there is a problem to be solved.

The remaining $15.48 \%$ representing 26 respondents disagreed that non-executive and independent directors are actively involved in formulating of strategies. According to them, formulation of strategies is a preserve of management team and the formulated strategies are only presented to the board for approval as well as sometimes meet to deliberate to solve problems which are beyond the management team. This is an indication of the fact majority of non-executive and independent directors in family businesses (unlisted) in Ghana are not involved in strategy formulation. These findings are not in consistent with results of [75] who concluded that non-executive directors on unlisted boards have a greater involvement in strategic development.

According to [78], emphasis on the monitoring role encourages non-executive directors to overturn poor deci- 
sions, or replace underperforming executives as a result of such monitoring in a timely fashion. Consequently, the replacement of non-performing executives by non-executive and independent directors is expected to enhance the performance of these businesses. However, the findings of this do not support Hypothesis 2. The findings shows no significant relationship between selection and removal of executive directors as roles of non-executive directors and performance of non-listed family businesses in Ghana. Non-executive and independent directors sampled for this study further indicated that their suggestions and decisions with regards to the selection and removal of executives, especially non-performing ones, are usually ignored because such executives may have close ties (family and friends) with others. In most cases, people selected to be executives lack the requisite skills and knowledge needed to advance the wellbeing of these businesses. Therefore, the selection and removal of executives in family businesses in Ghana are often characterized by favoritism and nepotism which limits the activities or involvement of non-executive and independent directors in the conduct of such role. This is supported by a study by [75] who posit there is further evidence that dominant shareholders impose undue pressure and lessen non-executive activity.

It makes headlines when prominent companies fail to adequately plan for orderly succession of leadership. In recent years, several Fortune 100 companies have found themselves grappling with the pitfalls that leadership vacuums can create, with the turbulent global economy only compounding the impact of those challenges [91]. In today's rapidly changing business environment, it's more critical than ever to have solid leadership bench strength and a rich talent pipeline to drive new initiatives and maintain a competitive edge. For instance, General Electric (GE) has discovered that systematic, rigorous, and ongoing succession planning has been an essential tool for its organization, and proposes that such effective and sustainable succession planning can be of value to companies of all sizes and across all industries and geographies [91]. This is supported by [92], former CEO of Medtronic, "One of the most important things leaders do is to prepare for their own succession” (p. 187). According to the Marketing Week Magazine, [93] According said, "Choosing a successor-in-chief is one of the most important decisions made by any organization, whether it is the cardinals in Rome selecting the next Pope or the United Kingdom wondering if the anointed successor is up to the job of King” (p. 24).

Distinguished economist Wharton [94] said, "One of the greatest dereliction of leaders is their failure to prepare or nurture their successors” (p. 270). The concept of succession planning has been defined as “a deliberate and systematic effort by an organization to ensure leadership continuity in key positions, retain and develop intellectual and knowledge capital for the future, and encourage individual advancement” [95]. Identifying and cultivating the person who will replace a CEO may not be second nature to some people. Yet without a systematic approach to assessing and developing the leadership talent needed across the business, a company can be caught unprepared by anticipated or unanticipated departures [91]. They [91] further stated that, a systematic approach allowed worldwide fast-food restaurant giant McDonald's to smoothly transition through the loss of two CEOs within seven months back in 2004_one to a sudden heart attack and his successor to a cancer diagnosis just weeks later.

The findings in this research are in contrast to the aforementioned literature as they do not support hypothesis 3. Consequently, there exist no significant relationship between succession planning as a role of non-executive directors and performance of family businesses in Ghana. The concern for non-executive directors in identifying a competent heir apparent is often relegated to the background by owners and executives of family businesses in Ghana. Succession planning of family businesses in Ghana is often characterized by severe internal political manipulations and power struggles especially among family members [81]. As a result, most family businesses in Ghana do not pass the second generation as well as subsequent generations and eventually wound up. That notwithstanding, when the family businesses are ran by the second and subsequent generations, the presence of outsiders (affiliated and independent) has no effect on performance [96] [97]. The findings in this research specifically relating to hypothesis 3 are in conformity to the argument advanced by Long et al., [75] who postulated that independent and non-executive directors on unlisted boards have a lesser involvement in the process of succession planning.

The study revealed the financial monitoring of non-executive directors in family businesses could not significantly impacted on the performance of the family businesses in Ghana. According to Gabrielsson and Winlund and Long et al., [75] [85], independent and non-executive directors on unlisted boards have a greater involvement in the monitoring of financial information. They further stated that UFB's suffer from inconsistent information due to vague divisions of responsibilities and absence of formal reporting systems. However, hypothesis 4a is at variance with the propositions espoused by Gabrielsson and Winlund and Long et al., [75] [85]. There- 
fore, financial monitoring as a role of non-executive and independent directors does not impact significantly on the performance of family businesses in Ghana. This means that non-executive and independent directors in Ghanaian family businesses have limited roles in monitoring the businesses that have engaged them financially. Most family businesses in Ghana lack professionals to keep the right books of accounts and as such lack formal reporting systems. Non-executive and independent directors of family businesses in Ghana are often kept in the dark with regards to financial transactions as well as ignored when details of such transactions are sought after by them.

Studies by Shleifer and Vishny [98] and Randoy and Goel [88] reveal that non-executive directors on unlisted boards have a reduced need to monitor executives due to the lack of agency issues. The limited role played by non-executive and independent directors in monitoring the performance of management (executives) is supported by Gabrielsson and Huse [90] as the study posits that information asymmetry and opportunism is lessened through close working and personal relationships between executives and non-executive directors. The findings of this study support hypothesis $4 \mathrm{~b}$, even though hypothesis $4 \mathrm{a}$ was rejected. This is an indication that management performance monitoring as a role of non-executive and independent directors though limited has a significant positive impact on the performance of family businesses in Ghana.

\section{Conclusions}

The effectiveness of the board or the lack thereof, have become a global concern. Corporate collapse, fraud cases, shareholders suit or questionable strategic decisions are attracting to the top decision making body of the organization, the board of directors (non-executive and executive directors). In an attempt to raise the standards of the corporate governance process, "codes of best practice" have been drawn up by several countries, global institutions and institutional investors' organizations and adverse publicity is created for companies with what are seen as ineffective governance systems. The issue of good corporate governance is, therefore, an imperative for ensuring successful corporate performance. Building good corporate governance is a shared responsibility among all shareholders, each of whom may exert pressure to move an institution in a slightly different direction. In this regard, although the motivations of the various players are different, they can and should be mutually supportive. The first major step in creating good governance is for all players to mutually agree on the common corporate goals, which must be specific, explicit and consistent. The process will result in trade-offs and delicate balancing of various interest groups. However, once the goals are determined and the respective roles of the various players are explicitly defined, there should be an incentive structure and sanctions, which must be effectively monitored and enforced. This study examines the role of non-executive and independent directors in ensuring corporate governance in non-listed family businesses in Ghana as well as determine whether such roles enhance the performance or otherwise of family businesses. The findings in this study as already discussed can be summarized as: strategic formulation, selection and removal of executives and succession planning as roles of non-executive directors have no significant impact on the performance of non-listed family businesses in Ghana.

However, management performance monitoring as a role of Non-executive directors has a significant positive impact on the performance of non-listed family businesses in Ghana. Therefore, a generalization can be postulated based on the findings and discussion of this study that the presence of non-executive and independent directors has no significant impact on the performance of non-listed family businesses in Ghana. This generalization is consistent with conclusion of a study by Arosa et al., [97] who conducted survey into the impact of presence outsiders on the board of directors on the performance of Spanish non-listed family firms. They [97] conclude that there is no significant relationship between independent directors and firm performance. Thus, firm performance is not affected by the presence of independent directors on the board. This assertion is supported by (Gupta et al., 2011) who opined that the mere presence of independent directors on a company's board is not enough. According to [99], there is a significant evidence (world-wide) of corporate failures and poor board performance even with adequate number of experienced independent directors. It is not, therefore, their mere presence on the board but the value that they add to the board process which will ensure effective corporate governance.

\section{Recommendations and Directions for Further Research}

Corporate governance is about promoting corporate fairness, transparency and accountability. In the wake of 
unprecedented scandals and the erosion of investor confidence, it is very imperative to acknowledge the fact that adhering to good governance processes and principles can make a noticeable difference to how investors view an organization. The board of directors (non-executives and executives) are ultimately responsible for governance, risk and control framework. Indeed, if a family business (listed or unlisted) or any company is really to embrace the spirit of good governance, risk management and internal control, it is suggested that the drive and motivation needs to come from within and more specifically from the top of the organization. The focus of this research is to examine the impact of roles of one of the types of directors (i.e. non-executive and independent directors) on performance of family businesses in Ghana. It has been established in this research and other available literature that the mere presence of non-executive and independent directors doesn't guarantee improved performances of businesses. Reiter and Rosenberg [100] are of the opinion that independent directors will bring the sort of rigor and critical analysis required to limit recurrences of debacles. Independent directors can be valuable to the companies they serve and therefore, they [100] recommended those companies should take their responsibilities seriously to provide appropriate, useful and timely information in order to harness optimum benefits from them. This study further recommends the following in order to realize positive impact of the presence and roles played by non-executive and independent directors on the performance of non-listed family businesses in Ghana so as to ensure good corporate governance in all companies in general.

Ghana's Companies Code, 1963, Act 179 has not caught up with current developments in the area of corporate governance such as the requirement for an audit committee of the board as well as separation of the roles of non-executives and independent directors and executive directors. The Ghana Stock Exchange Listing Regulations, which appear to somewhat more advance in terms of governance requirements, are applicable to only few listed companies. Moreover, due to weak surveillance systems and lack of enforcement of existing laws by the Registrar of Companies, the governance culture of enterprises has been extremely weak. In view of this, it is recommended that the appointment and terms of reference for non-executive and independent directors should be enshrined into the Companies Code, 1963, Act 179 and made mandatory for all for both listed and non-listed companies and businesses. The appropriate sanctions and penalties should also be made clear to all companies so as to deter them from flouting such provision. It is also recommended that existing laws and provisions should be strictly enforced to the latter by the appropriate supervisory and regulatory bodies in order to ensure good corporate governance which has long term effect of boosting the economy of Ghana as a whole. There should be massive public education to enlighten businesses on the need to adopt and implement good corporate governance practices.

Additionally, it is recommended that majority of the board members should be independent directors. An independent director should be independent of management and free of any business or other relationship that could materially interfere with—or could reasonably be perceived to materially interfere with—the exercise of their unfettered and independent judgement. The board should regularly assess the independence of each director in light of interests disclosed by them. Directors considered by the board to be independent should be identified as such in the corporate governance section of the annual report. The board should state its reasons if it considers a director to be independent notwithstanding the existence of relationships listed in.

Corporate performance is enhanced when there is a board (non-executive and executive directors) with the appropriate competencies to enable it to discharge its mandate effectively. An evaluation of the range of skills, experience and expertise on the board is therefore beneficial before a non-executive and independent director or any other candidate is recommended for appointment. Such an evaluation enables identification of the particular skills, experience and expertise that will best complement board effectiveness. Therefore, it is further recommended for the establishment of a nomination committee which should consist of ideally three members with the majority being non-executive and independent directors to carry out such mandate. The nomination committee should consider developing and implementing a plan for identifying, assessing and enhancing competencies of non-executive directors and other directors. This will help prevent selection of non-competent directors on the basis of nepotism and favoritism. The nomination committee should also consider whether effective succession plans are in place and constitute one if none exist in order to maintain an appropriate balance of skills, experience and expertise on the board. This will eliminate rivalry and in-fighting amongst family members who would want to be successors in their family businesses but lack the requisite knowledge and leadership skills to maintain and grow their businesses beyond the first generation. This will in the long run sustain and boost investors and clients' confidence in the businesses.

In support of their candidature for dictatorship, it is recommended that non-executive and independent direc- 
tors should provide the nomination committee with details of other commitments and indication of time involved. Non-executive and independent directors should specifically acknowledge to the company prior to appointment or being submitted for election that they will have sufficient time to meet what is expected of them. The nomination committee should regularly review the time required from a non-executive and independent director, and whether directors are meeting this. A non-executive director should inform the chairperson and the nomination committee before accepting any new appointments.

Good corporate governance ultimately requires people of integrity. Personal integrity cannot be regulated. However, investor and client confidence can be enhanced if the family business or company clearly articulates the practices by which it intends non-executive and independent directors and key executives to abide. Therefore, this study recommends that every family business or company should determine its own policies designed to influence appropriate behavior by both non-executive and executive directors as well as key executives. A code of conduct is an effective way to guide the behavior of internal stakeholders within the family business or company and demonstrate the commitment of the business to ethical practices. It is not necessary for a separate code for directors and key executives to be adopted by all organizations. Depending on the nature and size of the company's operations, the code of conduct for directors and key executives may be stand alone or be integrated into the corporate code of conduct of the organization.

Furthermore, an audit committee must be instituted which must compose of only non-executive and independent directors to review the financial transactions of the family business or company. The audit committee should review the integrity of the company's financial reporting and oversee the independence of the external auditors. Executive directors for that matter management should not shroud financial transactions in secrecy but avail every material information to the audit committee in a timely manner. The existence of an audit committee is recognized internationally as an important feature of good corporate governance. If there is no audit committee, it is particularly important that the family business or company should disclose how its alternative approach assures the integrity of the financial statements of the company and the independence of the external auditor, and why audit committee is not considered appropriate. The audit committee should include members who are financially literate and others who have an understanding of the industry in which they operate.

Corporate governance rules and practices cannot be separated from cultural and historical practices of the society. The family business or the company is a human response to the economic and social pressures in the generation of wealth and the relationship between the owners of capital and the managers of that capital. The central feature of corporate governance is a part of that response. It would serve little purpose, to attempt to find a complete global solution to corporate governance, which does not take into account the significant cultural and conceptual differences, expressed in the rules and practices on corporate governance in several jurisdictions including Ghana. Consequently, it is suggested that any corporate governance solution should reflect the cultural, social and economic background in which family businesses or companies are to operate. However, globalization of industry and cross-border transactions, are creating the need for a level of convergence of rules and practices such as the OECD principles, which establish certain basic parameters for good corporate governance [101]. In as much Ghana has to accept the general standards for corporate governance internationally recognized, she must at the same ensure that their application and implementation is coherent with its local economic and social contexts.

This study is not free from limitations, which have prompted avenues for future research. Firstly, there is limitation on the possibility of generalization of the findings of this study to other countries since the data for this study were exclusively collected in Ghana. The authors therefore encourage fellow researchers to conduct similar study in other countries and regions of the world. This would deepen understanding about board and corporate governance dynamics on a larger spectrum. Secondly, this research explored the impact of presence and roles of non-executive directors on the performance of UFB's in promoting good corporate governance. Further research could explore the relationship in other specific categories for example, in listed family businesses, in non-trading organizations, in government organizations, in the banking and financial institutions sector in Ghana. This would enable readers to have better appreciation of corporate governance roles in other types of organizations. This further research could address the similarities and differences of the roles in different organizations as well as consider the legal and regulatory requirements for different organizations in Ghana. Lastly, the data used for this research are cross-sectional in nature; therefore, a trend analysis or time series investigation into the practice of corporate governance by a company over a period of time was not possible. Fellow researchers may employ a longitudinal research design to explore whether practicing corporate governance in a company for a 
period of time leads to improved performance or otherwise.

\section{References}

[1] Halpern, P. (2000) Systemic Perspectives on Corporate Governance. Governance and Globalization, 1-58.

[2] Berglof, E. and Von Thadden, E.L. (1999) The Changing Corporate Governance Paradigm: Implications for Transition and Developing and Countries. Annual Bank Conference on Development Economics, Washington DC, 28-30 April 1999, 135-162.

[3] Hart, O. (1995) Corporate Governance: Some Theory and Implications. The Economic Journal, 105, 678-689. http://dx.doi.org/10.2307/2235027

[4] King, M.E. (2006) The Corporate Citizen: Governance for All Entities. Penguin Books, Johannesburg.

[5] Cadbury, A.S. (2000) Family Firms and Their Governance Creating Tomorrow’s Company from Today’s. London.

[6] SEC (2010) Corporate Governance Guideleines on Best Practices_Ghana. Securities \& Exchange Commission-Ghana (SEC), Accra-Ghana.

[7] Sarbah, A. and Xiao, W. (2015) Good Corporate Governance Structures: A Must for Family Businesses. Open Journal of Business and Management, 3, 40-57. http://dx.doi.org/10.4236/ojbm.2015.31005

[8] Davis, E. (2009) Do Ghanaian SMEs Need Corporate Governance Structures? Business \& Financial Times, Ghana. http://www.modernghana.com/newsthread1/245735/22/178420\#showcomments2

[9] Steel, W.F. and Webster, L.M. (1992) How Small Enterprises in Ghana Have Responded to Adjustment. World Bank Economic Review, 6, 423-438. http://dx.doi.org/10.1093/wber/6.3.423

[10] Aryeetey, E. (2001) Priority Research Issues Relating to Regulation and Competition in Ghana. Manchester.

[11] Abor, J. and Quartey, P. (2010) Issues in SME Development in Ghana and South Africa. International Research Journal of Finance and Economics, 39, 218-228.

[12] Mullineux, A.W. (1996) The Funding of Non-Financial Corporations (NFCs) in the EU (1971-1993): Evidence of Convergence. Mimeo, Department of Economics, University of Birmingham, Birmingham.

[13] Colley, J.L., Doyle, J.L., Logan, G.W. and Stettinius, W. (2003) Corporate Governance. McGraw-Hill, New York.

[14] Gregory, H.L. (2000) International Comparison of Corporate Governance Guidelines and Codes of Best Practice: Investor Viewpoints. Gotshal \& Manges and Egon Zehnder International, New York.

[15] Kenyon-Rouvinez, D. and Ward, J.L., Eds. (2004) Family Business: Key Issues. Palgrave Macmillan, London.

[16] IFC (2004) The Board of Directors in a Family Business. In: Family Business Governance Handbook, International Finance Corporation, 37-45.

[17] Ward, J.L. (1997) Growing the Family Business: Special Challenges and Best Practices. Family Business Review, 10, 322-337. http://dx.doi.org/10.1111/j.1741-6248.1997.00323.x

[18] Balshaw, T. (2004) Governance in Family Business. Institute of Directors, Johannesburg.

[19] Levitt, P. (2000) Transnational Migration and Development: A Case of Two for the Price of One? Global Networks, 1, 195-216.

[20] Adendorff, C.M. (2004) The Development of a Cultural Family Business Model of Good Governance for Greek Family Businesses in South Africa. eprints.ru.ac.za, Grahamstown.

[21] IFC (2008) Creating Opportunity: 2008 Annual Report. International Finance Corporations, Washington DC.

[22] Davis, J. (2001) Governing the Family-Run Business. HBS Working Knowledge, Vol. 4.

[23] Handler, W.C. (1989) Methodological Issues and Considerations in Studying Family Businesses. Family Business Review, 2, 257-276. http://dx.doi.org/10.1111/j.1741-6248.1989.00257.x

[24] Lansberg, I., Perrow, E.L. and Rogolsky, S. (1988) Family Business as an Emerging Field. Family Business Review, 1, $1-8$.

[25] Upton, N., Vinton, K., Seaman, S. and Moore, C. (1993) Research Note: Family Business Consultants-Who We Are, What We Do, and How We Do It. Family Business Review, 6, 301-311. http://dx.doi.org/10.1111/j.1741-6248.1993.00301.x

[26] Miller, E.J. and Rice, A.K. (1967) Systems of Organization: The Control of Task and Sentient Boundaries. Tavistock, London.

[27] Churchill, N.C. and Hatten, K.J. (1997) Non-Market-Based Transfers of Wealth and Power: A Research Framework for Family Business. Family Business Review, 10, 53-67. http://dx.doi.org/10.1111/j.1741-6248.1997.00053.x

[28] Habbershon, T.G. and Williams, M.L. (1999) A Resource-Based Framework for Assessing the Strategic Advantages of 
Family Firms. Family Business Review, 12, 1-25. http://dx.doi.org/10.1111/j.1741-6248.1999.00001.x

[29] Astrachan, J.H. and Shanker, M.C. (2003) Family Businesses' Contribution to the U.S. Economy: A Closer Look. Family Business Review, 16, 211.

[30] Litz, R.A. (1995) The Family Business: Toward Definitional Clarity. Family Business Review, 8, 71-81. http://dx.doi.org/10.5465/AMBPP.1995.17536337

[31] Westhead, P. and Cowling, M. (1998) Family Business Research: The Need for a Methodological Rethink. Entrepreneurship Theory and Practice, 23, 31-57.

[32] Colli, A., Pérez, P.F. and Rose, M.B. (2003) National Determinants of Family Firm Development? Family Firms in Britain, Spain, and Italy in the Nineteenth and Twentieth Centuries. Enterprise \& Society, 4, $28-64$. http://dx.doi.org/10.1093/es/4.1.28

[33] Colli, A. and Rose, M. (2008) Family Business. No. 20.

[34] Sharma, P. (2004) An Overview of the Field of Family Business Studies: Current Status and Directions for the Future. Family Business Review, 17, 1-36. http://dx.doi.org/10.1111/j.1741-6248.2004.00001.x

[35] Brunaker, S. (1996) Introducing Second Generation Family Members into the Family Operated Business-A Constructionist Approach. Ph.D. Dissertation, Swedish University of Agricultural Sciences, Uppsala.

[36] Brunaker, S. (1999) Understanding the Succession Process in Family Businesses. In: Johannisson, H. and Landstrom, B., Eds., Images of Entrepreneurship and Small Business, Studentlitteratur, Lund, 35-57.

[37] Hoy, F. and Verser, T.G. (1994) Emerging Business, Emerging Field: Entrepreneurship and the Family Firm. Entrepreneurship Theory and Practice, 18, 23.

[38] Scase, R. and Goffee, R. (1982) The Entrepreneurial Middle Class. Croom Helm, London.

[39] Morck, R., Shleifer, A. and Vishny, R.W. (1988) Management Ownership and Market Valuation. Journal of Financial Economics, 20, 293-315. http://dx.doi.org/10.1016/0304-405X(88)90048-7

[40] Emmons, W.R. and Schmid, F.A. (1999) Corporate Governance and Corporate Performance. In: Stephen, S.C. and Gavin, B., Eds., Corporate Governance and Globalization: Long Range Planning Issues, Edward Elgar, Massachusetts, 59-94.

[41] Gompers, P., Ishii, J. and Metrick, A. (2003) Corporate Governance and Equity Prices. Quarterly Journal of Economics, 118, 107-155. http://dx.doi.org/10.1162/00335530360535162

[42] Severin, E. (2001) Ownership Structure and the Performance of Firms: Evidence from France. European Journal of Economic and Social Systems, 15, 85-107. http://dx.doi.org/10.1051/ejess:2001117

[43] Drobetz, W., Schillhofer, A. and Zimmerman, H. (2004) Corporate Governance and Expected Stock Returns: Evidence from Germany. European Financial Manaement, 10, 267-293. http://dx.doi.org/10.1111/j.1354-7798.2004.00250.x

[44] Klapper, L.F. and Love, I. (2004) Corporate Governance, Investor Protection, and Performance in Emerging Markets. Journal of Corporate Finance, 10, 703-728. http://dx.doi.org/10.1016/S0929-1199(03)00046-4

[45] Brown, L.D. and Caylor, M.L. (2006) Corporate Governance and Firm Valuation. Journal of Accounting and Public Policy, 25, 409-434. http://dx.doi.org/10.1016/j.jaccpubpol.2006.05.005

[46] Bistrova, J. and Lace, N. (2010) Ownership Structure in CEE Companies and Its Influence on Stock Performance. Enterpreneurship Management, 15, 880-885.

[47] Walls, J.L., Berrone, P. and Phan, P.H. (2012) Corporate Governance and Environmental Performance: Is There Really a Link? Strategic Management Journal, 33, 885-913. http://dx.doi.org/10.1002/smj.1952

[48] Ramon, V.R. (2001) Corporate Governance as Competitive Advantage in Asia. Managing Corporate Governance in Asia. Asian Institute of Management, Philippines.

[49] Ruin, J.E. (2001) Essentials of Corporate Governance. MICG, Malaysia.

[50] Van Den Heuvel, J., Van Gils, A. and Voordeckers, W. (2006) Board Roles in Small and Medium-Sized Family Businesses: Performance and Importance. Corporate Governance, 14, 467-485. http://dx.doi.org/10.1111/j.1467-8683.2006.00519.x

[51] Castaldi, R. and Wortman, M.S. (1984) Board of Directors in Small Corporations: An Untapped Resource. American Journal of Small Business, 9, 1-11.

[52] Ford, R.H. (1992) Boards of Directors and the Privately Owned Firm. Quorum Books, New York.

[53] Borch, O.J. and Huse, M. (1993) Informal Strategic Networks and Boards of Directors. Entrepreneurship Theory and Practice, 18, 23-36.

[54] Watkins, D. and Shen, Y. (1997) Criteria for Board Construction in the Entrepreneurial Firm. In: XI Research in Entrepreneurship and Small Business (RENT XI). 
[55] Poutziouris, P.Z. (2001) The Views of Family Companies on Venture Capital: Empirical Evidence from the UK Small to Medium-Size Enterprising Economy. Family Business Review, 14, 277-291. http://dx.doi.org/10.1111/j.1741-6248.2001.00277.x

[56] Dyer, W.G.J. (1986) Cultural Chang e in Family Firms. Anticipating and Manag ing Business and Family Transitions. Jossey-Bass, San Francisco.

[57] Thorning-Lund, S. (2012) Keeping It in the Family? How Independent Directors Add Value to Family Businesses. Odgers Berndtson, London, 12.

[58] Mueller, K.R. (1988) Differential Directorship: Special Sensitivities and Roles for Serving the Family Business Board. Family Business Review, 1, 239-247. http://dx.doi.org/10.1111/j.1741-6248.1988.00239.x

[59] Horowitz, S. (2008) Sam Steinberg’s Non-Lasting Legacy. UMass Amherst Family Business Center.

[60] Gibb Dyer, W. (1986) Cultural Change in Family Firms: Anticipating and Managing Business and Family Transitions. Jossey-Bass Inc. Publishers, San Francisco.

[61] Fischer, H. and Stevenson, J. (2007) Building the High-EQ Board, Summer. FAM. BUS. MAG., 2.

[62] Stone, D. (2007) The Outsiders. Fam. Bus. Mag., 4.

[63] Cohn, M. (2003) Are You Ready for “Outsiders”? Fam. Bus. Mag., 2.

[64] Osi, C. (2009) Family Business Governance and Independent Directors: The Challenges Facing an Independent Family Business Board. University of Pennsylvania Journal of Business Law, 12, 181.

[65] Rashid, A., De Zoysa, A., Lodh, S. and Rudkin, K. (2010) Board Composition and Firm Performance : Evidence from Bangladesh. Australas Account Bus Finance Journal, 4, 76-95.

[66] Kaplan, S.N. and Reishus, D. (1990) Outside Directorship and Corporate Performance. Journal of Financial Economics, 27, 389-410. http://dx.doi.org/10.1016/0304-405X(90)90061-4

[67] Byrd, J.W. and Hickman, K.A. (1992) Do Outside Directors Monitor Managers? Evidence from Tender Offer Bids. Journal of Financial Economics, 32, 195-222. http://dx.doi.org/10.1016/0304-405X(92)90018-S

[68] Brickley, J.A., Coles, J.L. and Terry, R.L. (1994) Outside Directors and the Adoption of Poison Pills. Journal of Financial Economics, 35, 371-390. http://dx.doi.org/10.1016/0304-405X(94)90038-8

[69] Beasley, M.S. (1996) An Empirical Analysis of the Relation between the Board of Director Composition and Financial Statement Fraud. The Accounting Review, 71, 443-465.

[70] Rosenstein, S. and Wyatt, J.G. (1990) Outside Directors, Board Independence and Shareholders Wealth. Journal of Financial Economics, 26, 175-191. http://dx.doi.org/10.1016/0304-405X(90)90002-H

[71] Judge, W.Q., Naoumova, I. and Koutzevol, N. (2003) Corporate Governance and Firm Performance in Russia: An Empirical Study. Journal of World Business, 38, 385-396. http://dx.doi.org/10.1016/j.jwb.2003.08.023

[72] Kumar, N. and Singh, J.P. (2012) Outside Directors, Corporate Governance and Firm Performance: Empirical Evidence from India. Asian Journal of Finance \& Accounting, 4, 39-55. http://dx.doi.org/10.5296/ajfa.v4i2.1737

[73] McNulty, A., Roberts, J. and Stiles, P. (2002) Creating Accountability within the Board: The Work of the Effective Non-Executive Director.

[74] Pye, A. (2000) Changing Scenes In, From and Outside the Board Room: UK Corporate Governance in Practice from 1989-1999. Corporate Governance, 8, 335-346. http://dx.doi.org/10.1111/1467-8683.00212

[75] Long, T., Dulewicz, V. and Gay, K. (2005) The Role of the Non-Executive Director: Findings of an Empirical Investigation into the Differences between Listed and Unlisted UK Boards. Corporate Governance, 13, 667-679. http://dx.doi.org/10.1111/j.1467-8683.2005.00458.x

[76] Kisfalvi, V. (2000) The Threat of Failure, the Perils of Success and CEO Character: Sources of Strategic Persistence. Organization Studies, 21, 611-639. http://dx.doi.org/10.1177/0170840600213006

[77] Cannella, A. and Monroe, M. (1997) Contrasting Perspectives on Strategic Leaders: Towards a More Realistic View of Top Managers. Journal of Management, 23, 213-237. http://dx.doi.org/10.1177/014920639702300302

[78] Brudney, V. (1985) Corporate Governance, Agency Costs and the Rhetoric of Contract. Columbia Law Review, 85, 1403-1444.

[79] Vancil, R. (1987) Passing the Baton. Harvard University Press, Boston.

[80] Lorsch, J.W. and MacIver, E. (1989) Pawns or Potentates: The Reality of America's Corporate Boards. Harvard University Graduate School of Business Administration, Boston.

[81] Pfeffer, J. (1981) Management as Symbolic Action: The Creation and Maintenance of Organisational Paradigms. In: Cummings, B.S.L., Ed., Research in Organizational Behavior, Vol. 3, CT JAI Press, Greenwich, 1-52.

[82] Boeker, W. and Goodstein, J. (1993) Performance and Successor Choice: The Moderating Effects of Governance and 
Ownership. Academy of Management Journal, 36, 172-186. http://dx.doi.org/10.2307/256517

[83] Cannella, A.A. and Lubatkin, M.H. (1993) Succession as a Sociopolitical Process: Internal Impediments to Outsider Selection. Academy of Management Journal, 36, 763-793. http://dx.doi.org/10.2307/256758

[84] Zajac, E.J. and Westphal, J.D. (1996) Who Shall Succeed-How CEO Board Preferences and Power Affect the Choice of New CEOs. Academy of Management Journal, 39, 64-90. http://dx.doi.org/10.2307/256631

[85] Gabrielsson, J. and Winlund, H. (2000) Boards of Directors in Small and Medium-Sized Industrial Firms: Examining the Effects of the Board's Working Style on Board Task Performance. Entrepreneurship \& Regional Development, 12, 311-330. http://dx.doi.org/10.1080/08985620050177930

[86] Daily, C.M. and Dalton, D.R. (1993) Board of Directors Leadership Structure: Control and Performance Implications. Entrepreneurship \& Regional Development, 17, 65-81.

[87] Shleifer, A. and Vishny, R.W. (1997) A Survey of Corporate Governance. The Journal of Finance, 52, 737-783. http://dx.doi.org/10.1111/j.1540-6261.1997.tb04820.x

[88] Randoy, T. and Goel, S. (2003) Ownership Structure, Founder Leadership, and Performance in Norwegian SMEs: Implications for Financing Entrepreneurial Opportunities. Journal of Business Venturing, 18, 619-637. http://dx.doi.org/10.1016/S0883-9026(03)00013-2

[89] Deakins, D., O’Neill, E. and Mileham, P. (2000) The Role and Influence of External Directors in Small Entrepreneurial Companies: Some Evidence on VC and Non-VC Appointed External Directors. Venture capital, 2, 111-127. http://dx.doi.org/10.1080/136910600295738

[90] Gabrielsson, J. and Huse, M. (2002) The Venture Capitalist and the Board of Directors in SMEs: Roles and Processes. Venture Capital, 2, 125-146. http://dx.doi.org/10.1080/13691060110094397

[91] Capital, G. (2012) Succession or Failure: Why Succession Planning Is Key to Long-Term Success. http://www.gecapital.ca/GECA_Document/Succession\%20or\%20Failure-\%20Why\%20succession\%20planning\%20is \%20key\%20to\%20long-term\%20success.pdf

[92] George, B. (2003) Authentic Leadership. Jossey-Bass, San Francisco.

[93] Marketing Week Magazine (2005) Following the Leaders. Retrieved 5 May 2005 from ProQuest.

[94] Wharton Jr., C.R. (2005) Personal Reflections on Leadership. Vital Speeches of the Day, 71, 270.

[95] Rothwell, W. (2001) Effective Succession Planning. American Management Association, New York.

[96] van den Heuvel, J., Goel, S., Van Gils, A. and Voordeckers, W. (2007) Family Businesses as Emotional Arenas: The Influence of Family CEO's Empathy and External Monitoring on the Importance of Family Goals. Res. Cent. Innov. Entrep., 1-45.

[97] Arosa, B., Iturralde, T. and Maseda, A. (2010) Outsiders on the Board of Directors and Firm Performance: Evidence from Spanish Non-Listed Family Firms. Journal of Family Business Strategy, 1, 236-245. http://dx.doi.org/10.1016/j.jfbs.2010.10.004

[98] Shleifer, A. and Vishny, R.W. (1997) A Survey of Corporate Governance. The Journal of Finance, 52, 737-784.

[99] Gupta, S.L., Hothi, B.S. and Gupta, A. (2011) Corporate: Independent Directors in the Board. Global Journal of Management and Business Research, 11, 57-74. http://dx.doi.org/10.1111/j.1540-6261.1997.tb04820.x

[100] Reiter, B.J. and Rosenberg, N. (2003) Meeting the Information Needs of Independent Directors. Ivey Business Journal. [101] OECD (1999) OECD Principles of Corporate Governance. Washington DC. 